\title{
CHEMICO-GENETIC CLASSIFICATION OF THE MOST IMPORTANT MINERALS-SATELLITES OF THE DIAMOND.
}

\author{
Bushueva, E.B.; Varlamov, D.A.; Garanin, V.K.; Kudrjavtseva, G.P.; Laverova, T.N. and Schepina, N.A. \\ Geological Department of Moscow State University, 119899, Lenin's Hills, Moscow, USSR.
}

Typomorhic peculiarities of the chemical composition and physical properties of the main ninerals-satellites of the diamond (garnet, alinopyrusene, orthopyrouene, chrome seinellide, ilmenite, rutilu) are of great impur and ho by the searching for the diamond depusi $L$ s ( kimberlites, lamproites and others) and estimation of their productivity. These minerals uccur in the kimberlites as madrystals, inclusions in diamond and in the diamond bearing peridotites and eclogites. A lot of works, incluling genelizing ones ( Sobolev, 1974; Gurney, Moore, 1989; Garanin et al, 1990) are devoted to the application of the indirect mineralogical criteria during the estimation of the kimberlite diaruond bearing. Chemico-genetical classifications of the diamond minerals-satelites represent the basis for the improvement of the known criteria of diamoml horing and for the development of the new ories.

The lata lanks and abemico-ybretic: aldssirication of the most important minerals from all the inclusions in the diamond and from the aygregalions with it. from the diamond bearing and nondiarnond bearing xenolithes, peridotites, and eclogites as well as from riegacrystals from the kimberlite rocks. The created data bank is: based un more than 4000 electron-probe andyses if both original minera? $\mathrm{k}$; and the ones borrowed from numerous literature? sources:

The software usel during the work with data base on the chemistry of minerals-sateliltes of the diamond includes statistical methods (cluster analysis and others), which are app1 ied luring the creation of chemico-genetic classifications. The rathud of the discriminant analysis is used to compare newly input electron-probe analyses with ones which already in the data bank and tu refer them to the corresponding cheritij-genetic sroup according tu the ocofficients values of the graphed discriminant functions.

The software ensures the derinition of the correldions of diamond bearing and nondiamond bearing paragenesis in the analised samples of minerals with the graphing of linear (column) and circle diagrams. Besidt: the packet of the applied programfiles has been lievelupell to carry out traditional re-calculation of MS andyses (the calculatiom of minals, crystallochemical coefficients and indicatur relation), graphreflection of analytical results (printing of liagrams and histograms) and statistiral processing within the range of every one from the separated claster and chemico-genetic groups ( calculation of average contents, ruot-mean-square deviation, carring out of the correlation analysis and so un.).

The software allows to evaluate the rocks productivity with the application of all known by now indirect mineralogical methods and to inprove che latter in the future.

The developed chemico-genetic olassifications of mineralssutellites are the basis for the usage of the automatised sys1. wus to obtain the woject.jve information about the diamond bea- 
ring of the tested object in the relation of minerals-satellitess of diamond bearing and nondiamond bearing paragenesis, about the contribution of the rocks of ultra basic or eclogite paragenesis into the diamond bearing of the tested object.

References:

1. Garanin, V.K., Kudrjavtseva, G.P., Mikhailichenko, O.A., and Marfunin, A.S. (1990) The inclusions in diamond and diamoni bearing rocks, 272 p., Moscow University, Moscow

2. Gurney, J.J., and Moore, R.O. (1989) Geochemical correlations between kimberlitic indicator minerals and diamonds. The development of advanced technology to distinguish between diamondiferous and barren diatrems. Can.Geol.Survey, p. 1-15

3. Sobolev, N.V.(1974) Deep seated inclusions in kiruberites and the problem of the composition of the upper mantle. English Translation by Brown, D.A., 1977, A.G.U., Washingtom $\mathrm{D} . \mathrm{C}$. 